such as "Although the domination of science by politics during both these periods had an adverse effect on scientific development and on the economy in general, there was also a growing body of opinion that these massive campaigns were a necessary pre-requisite to generating political will for Mao-style development" (page 219), it becomes difficult to know which growing body of opinion is being considered.

Nevertheless, considerable printing errors apart, this volume of essays will remain a valuable source, as much a reflection of western social ideals in the 1970s, as of China's development. Not unexpectedly, for a collective work by different authors, written at different times and clearly aimed at different levels (a few no doubt originally intended as University lectures), there are repetitions of facts and discontinuities in style which detract from the overall impression of the book. But it does raise pertinent questions in the light of China's present changing policies: can similar development goals be achieved by roads other than that of revolution? The answer today may be very different from that which seemed obvious not so very long ago.

The re-writing of any chapter of history, particularly when done at a distance, calls for no small amount of self-assessment. Leo Orleans, long respected as an analyst of Chinese affairs, expresses the new western dilemma: "It is possible to feel some regret that her [China's] drastic veering did not settle on some more middle course. Mao's dedication to the creation of an egalitarian society, his "serve the people" ethic, the sense of idealism he attempted to instill in the people, captured imaginations outside China as well as within, and some of those who disagreed with China's politics and policies could still identify with Mao's utopian ideals, [which] set China apart from every other nation" (page 225). By choosing a new and different road to development, China has set not only new goals for itself, but also a whole set of fresh criteria for western analysts.

M. Christine King is researching into Chinese Affairs and the History and Philosophy of Science.

\section{Higher marine fungi}

\section{R. A. Eaton}

Marine Mycology: The Higher Fungi. By J. Kohlmeyer and E. Kohlmeyer. Pp. 690. (Academic: New York and London, 1979.) $\$ 59.50 ; £ 34.60$.

FOR 20 years, the authors' research in the field of marine mycology has produced a high quality of illustration and description of marine fungi, particularly through their Icones Fungorum Maris and Synoptic Plates of Higher Marine Fungi. A large part of this volume combines the essence of these publications to give us the most comprehensive work since Johnson and Sparrows (Fungi in Oceans and Estuaries, J. Cramer: Lehre, FRG, 1961) that any student of marine fungi would need.

More than half of the book comprises illustrated keys, and descriptions of higher marine fungi including 90 plates of micrographs. But is photographic representation the best means of illustration? Certainly the beautifully accurate line drawings in the Icones are not surpassed by many micrographs in this book. Their use of interference contrast microscopy introduces a new dimension for observing the appendaged ascospores of many marine fungi, but has its limitations in aiding interpretation of sectioned ascocarps or spermogonia, and non-appendaged spores.
Parasitic and saprobic marine fungi exist on various natural and man-made substrates from mangrove vegetation to polyurethane. They are distributed in different geographical zones and at different depths in the oceans. The book deals very comprehensively with the factors which affect the occurrence of filamentous fungi and yeasts in the sea, but the authors consider only a "selection of pertinent papers" on their physiology and biochemistry.

Other chapters are concerned with methodology, fruit body and spore ontogeny, and the release, dispersal and settlement of spores. The fascinating relationships which exist between fungi and marine animals (particularly marine wood borers) and between fungi and algae (producing marine lichens), are also covered. Apart from a chapter on marine yeasts this book is concerned wholly with filamentous higher fungi, as the title states. For the sake of completeness, was it not possible to broaden the scope of the book a little, and include more than a mention of the lower marine fungi - one-fifth of the total marine mycota?

The authors state that "a major objective of this treatise is to assist students of marine fungi in the identification of species." This is achieved, for it is unquestionably a reference book to be kept on the shelf above the microscope.

R.A. Eaton is Senior Lecturer in the Department of Biological Sciences, Portsmouth Polytechnic, UK.
Announcing

BIOLOGICAL RHYTHMS AND THEIR
CENTRAL MECHANISM

edited by MASAMI SUDA, OSAMU HAYAISHI and HACHIRO NAKAGAWA

\section{A NAITO FOUNDATION SYMPOSIUM}

\section{0 pages \\ Price: US \$83.00/Dfl. 170.00 ISBN 0-444-80136-7}

This book, dealing with one of the most exciting subjects in biology and medicine today, offers the first rigorous examination into the sites of "biological clocks" in animals, the mechanisms of action and their relationships to environmental factors.

CONTENTS: Preface. List of Contributors Chapters 1. Principle of circadian organization. S. Pittendrigh. 2. Metabolic oscillation. B. Hess, T. Ishikawa, M. Nakamura, S. Nakamura, I. Yamazaki and K.-N. Yokota. 3. Cellular basis of biological clock. R.B. Alvarez, R. Denison, J.F Feldman, G. Gardner, K. Goshima, F Strumwasser, D.P. Viele and J.C. Woolum 4. Avian circadian system. K. Homma, M. Menaker, M. Ohta, Y. Sakakibara and J.S. Takahashi. 5. Physiological significance and control mechanism of pineal hormone rhythm in mammals. $D$. Auerbach, T. Deguchi, O. Hayaishi, D.C. Klein, H.J. Lynch, S. Reppert, L. Tamarkin, J. Weller, R.J. Wurtman, R. Yoshida and M. Zatz. 6. Factors entraining circadian rhythms in mammals. C.A. Czeisler, K. Hanada, T. Hiroshige, K.-l. Honma, M.C. Moore-Ede, Y. Morimoto, K. Takahashi, Y. Takahashi, E.D. Weitzman and Y. Yamamura. 7. Control mechanism of circadian rhythms apparently generated in relation to food intake. $Y$. Abe, $Y$. Habara, K. Ishikawa, S. Ishizuka, $T$ Kanno, K. Kida, J. Mizoguchi, K. Nagai, H. Nakagawa, T. Nishio, H. Nishino, T. Ono, $Y$. Oomura, A. Saito, $M$. Saito, $K$ Sasaki, N Shimizu, T Shimazu, $M$ Suda. 8. Suprachiasmatic nucleus as the circadian clock in mammals. L.C. Davidsen, N. Ibuka, T. Inouye, H. Kawamura, R.Y. Moore, W.J. Schwartz, Shin-lchi, C.B. Smith and I. Zucker. 9. Circadian rhythms without any possible relation to the suprachiasmatic nucleus. S. Aral, C.A. Fuller, E. Halberg, F. Halberg. J.Halberg, M.C. Moore-Ede, T. Nakayama, F.M. Sulzman and K. Yakamoto. 10. General Discussion. Subject Index.

\section{ELSEVIER/NORTH HOLLAND}

\section{BOMEDCAI PIRESS}

\section{P.O. Box 211, Amsterdam,}

The Netherlands

Distributor in the U.S.A. and Canada: ELSEVIER NORTH-HOLLAND, INC. 52 Vanderbilt Ave., New York, NY 10017

The Dutch guilder price is definitive. US $\$$ prices are subject to exchange rate fluctuations. 